there is an even larger area of private and village forest lands. Probably about half of the 160 million acres of forests under the control of the Indian Forest Department are commercially productive, the other half being conserved for the use of right holders or serving as purely 'protection forests'. In spite of this, the revenue has risen from 70 lakhs (a surplus of 17 lakhs) in 1870 to 6 crores of rupees (surplus $2 \frac{1}{2}$ crores) in 1930. Research has, so far, cost Rs. $3 \cdot 6$ per square mile, as against a surplus of Rs. 105 per square mile.

\section{Agricultural Research in Great Britain}

THE report on the agricultural research work carried out in Great Britain with the aid of State funds during the year 1930-31 has now been pub. lished by the Ministry of Agriculture (London: H.M. Stationery Office, 1932). The volume, which aims at presenting in convenient form the progress made at the various research institutes and other centres in Great Britain, is planned on the same lines as that issued in the preceding year, with the additional feature of a list, at the end of each report, of papers published during the year by the institute or research centre in question. References to the papers will be found in the text, and the lists will take the place of the annual volumes of "Abstracts of Papers on Agricultural Research in the United Kingdom", the publication of which has been discontinued. It is evident that many important results have been obtained in a number of branches of the subject, but the investigations are too numerous and cover too wide a field to allow of even brief reference being made to them individually. Those desiring further information regarding any subject dealt with in the reports are invited to communicate with the director or other persons concerned, for which purpose a list of names and addresses of directors of research institutes and persons in charge of investigations at other centres is given in the appendix.

\section{High Pressure Boilers}

A PAPER on high pressure boilers read to the Institution of Electrical Engineers on December 15 by C. H. Davy and C. H. Sparks gives an interesting account of the development of the use of very high pressure steam in modern boilers. Prior to 1918 , no plants had been placed in commercial service with steam pressures exceeding $350 \mathrm{lb}$. per sq. in. In 1923 the Edison Company at Boston ordered the first boiler unit suitable for a pressure of 1,200 lb. per sq. in. The construction of this boiler was made possible by the use of the first seamless forged steel boiler drum. Recent developments of X-ray technology have given the manufacturer of welded drums the long sought non-destructive test. A definite proof of the satisfactory condition of a metallic arc fusion weld can now be given by radiographic examination. By means of scientifically controlled welding, drums can be produced which are more suitable for working conditions than the riveted structures used in the past. The drums forming part of the $1,400 \mathrm{lb}$. per sq. in. pressure sectional boilers at present being installed at the Dagenham plant of the Ford Motor Co. are $45 \mathrm{ft}$. long, $48 \mathrm{in}$. in internal diameter, $5 \mathrm{in.}$ thick and weigh 62 tons. The production of such forgings reflects great credit on the forge-masters. Whilst the trend of invention has been definitely towards higher final steam temperatures, it is probable that these will be limited, at least for the present, to below $850^{\circ} \mathrm{F}$. This is due to the fact that the cost of 'special' steels is still very high and so it is not economical to use them. The Philip Carey Works at Ohio, which started last year, use a steam pressure of $1,800 \mathrm{lb}$. per sq. in. The demand for high pressures and consequently high temperatures continues for power stations but super-pressure boilers are mainly used in industrial work.

\section{Map of East Greenland}

A NEW map on a scale of $1: 200,000$ of the coastlands of East Greenland between Sofia Sound in about lat. $73^{\circ} \mathrm{N}$. and Young Sound in about lat. $74^{\circ} 10^{\prime} \mathrm{N}$. based on surveys by Norwegian expeditions in 1929 and 1931 has been published by Norges Svalbard og Ishavs-Undersökelser. This includes the coasts to the north and south of the Norwegian meteorological observatory at Myggbukta in Mackenzie Bay in lat. $73^{\circ} 29^{\prime} \mathrm{N}$., long. $21^{\circ} 34^{\prime} \mathrm{W}$. This coast was first sighted by Hudson in 1607 and has since been explored by various expeditions, including those of Clavering in 1823, Nathorst in 1899 and in the north by Wordie in 1926. While much detail is still omitted, the new chart shows many advances on previous ones.

\section{Anti-Veterinary Propaganda}

IN the autumn issue of The Fight Against Disease, the quarterly journal of the Research Defence Society, attention is directed to the attacks which antivivisectionists, and notably the National Antivivisection Society, have made and persist in making on the Royal Veterinary College and on any other organisation which helps to further veterinary science, with attempts to divert funds from the Tail Wagger's Club. In regard to the last named, the governors of the College have stated that no part of the funds or income arising therefrom is applied in vivisectional experiments. Prof. F. T. G. Hobday, whose name appeared in the New Year honours list as the recipient of a knighthood, the principal of the Royal Veterinary College, in the recent Alexander Pedler Lecture of the British Science Guild (British Science Guild, 6 John Street, London, W.C.2. 1s.), also emphasises the humane side of veterinary practice for the animals themselves, and declares our deep and heavy responsibility in ensuring that we act humanely towards the animals in our charge.

\section{Collecting and Preserving Worms}

A USEFUL guide for the collector, No. 12 of the British Museum (Natural History) series of "Instructions for Collectors", deals with the various groups of worms. Short descriptions and illustrations are given of the characteristic features of the main groups, with hints as to the places where they are 
likely to be found. But the most serviceable features are the precise instructions for collecting worms, free and parasitic, and for anæsthetising and preserving them. The pamphlet, of 22 pages, is sold at the British Museum (Natural History) at $6 d$.

\section{Ultra-Violet Light at British Health Resorts}

Figures of the amount of ultra-violet light enjoyed by thirty-two British health resorts during the summer months, July, August, and September, are given in Sunlight (vol. 2, No. 7, p. 209). St. Ives heads the list with a daily average of $6 \cdot 6$ 'units', and none had less than $1 \cdot 3$ units. Half a unit is sufficient to cause perceptible sunburn.

\section{Spring Lectures at the Royal Institution}

THE session of public afternoon lectures at the Royal Institution was opened by Prof. J. C. McLennan, who is giving an experimental course on the work on "Low Temperatures and Low Temperature Phenomena" with which he and the University of Toronto have been specially identified. A course on "Recent Advances in Genetics" is to be given by Prof. J. B. S. Haldane, who has recently returned from a visit to the laboratories at the University of California and elsewhere in the United States. Later courses are by Sir William Bragg, who will review the progress in the past twenty years of the science of crystal analysis by $\mathrm{X}$-rays; and $\mathrm{Mr}$. A. R. Hinks, secretary of the Royal Geographical Society, on "Geography in the Public Service". Mr. Hinks will speak on the new one inch Ordnance Survey map, and the delimitation of national boundaries. Lord Rutherford will give a Saturday course on the "Detection and Production of Swift Particles". The course will be experimental, and as a part of his subject Lord Rutherford will describe the recent progress at the Cavendish Laboratory by Chadwick, Cockroft and Walton and others. Sir James Jeans will give a course on "Modern Astronomy". The new Fullerian professor of physiology at the Royal Institution, Prof. G. Elliot Smith, will give a course on the "Evolution of the Mind". The session will conclude with a display of films, entitled "Developments in Cinematography". Instructional films, colour films, and films in relation to aeronautical research will be shown.

\section{Announcements}

Aт a meeting of the Harrison Memorial Prize Selection Committee on January 13, the Harrison prize for 1932 was awarded to Dr. H. J. Emelóus, of the Imperial College of Science, London.

Tre Gold Medal of the Royal Astronomical Society has been awarded this year to Dr. V. M. Slipher, director of the Lowell Observatory, for his spectroscopic researches on planets, stars and nebulæ. Dr. Slipher has been invited to deliver the George Darwin Lecture for 1933. At the annual general meeting of the Society on February 10, the president, Dr. H. Knox-Shaw, will deliver an address on "The Distances and Motions of the Extra-Galactic Nebulæ".
Tне following have been appointed to the Safety in Mines Research Board: Dr. C. V. Drysdale, director of Scientific Research at the Admiralty, Mr. F. Edmond, chief mining agent to the Wigan Coal Corporation, Ltd., and Major H. M. Hudspeth, chief mining engineer to the Board. The appointment of Prof. J. F. Thorpe would normally have ended on December 31 last, but Prof. Thorpe has accepted a special extension of his term of service for a period of two years. Prof. C. H. Lees, whose appointment was specially extended at the end of 1931, has now completed his term of service.

DR. R. R. Marett, Rector of Exeter College, Oxford, has been appointed Donnellan lecturer for 1933 in Trinity College, Dublin. The lecture will probably be delivered in the second week in May. An earlier date than usual is being arranged to suit Dr. Marett's other engagements. He has announced the subject of the lecture as "Pre-theological Religion in Feeling, Thought and Action".

A course of four public lectures entitled "An Introduction to Indian Archæology" will be given by Mr. F. J. Richards, honorary lecturer in Indian archæology at University College, London, beginning on Tuesday, January 24, at 5.30 P.M., and thereafter at the same time on each Tuesday until February 14. The subjects of the lectures will be : physical factors; human factors ; religious complexities ; arts, useful and otherwise. The lectures are open and the public will be admitted without fee or ticket.

By arrangement with the Polytechnic, Regent Street, London, and the National Illumination Committee and the Illuminating Engineering Society, a course of ten lectures on illumination will be given at the Polytechnic on Wednesdays beginning February 8 . The lectures will deal with various aspects of illumination and will be delivered by experts in the respective subjects. Further information can be obtained from the Director of Education, The Polytechnic, 309 Regent Street, W.1.

ApPlications are invited for the following appointments, on or before the dates mentioned :--A wholetime abstractor and translator (at Sheffield) for the Safety in Mines Research Board-The UnderSecretary for Mines, Establishment Branch, Cromwell House, Dean Stanley Street, Millbank, London, S.W.1 (Feb. 4). A public and agricultural analyst and gas examiner for the County of Derbyshire-The Clerk to the County Council, County Offices, Derby (Feb. 4). A librarian for the Halesowen Urban District Council-The Clerk, Cornbow House, Halesowen (Feb. 10). A specialist in biochemistry and physiology in relation to food and nutrition on the medical staff of the Ministry of Health-The Director of Establishments, Ministry of Health, Whitehall, S.W. (Feb. 13). A metropolitan meat industry commissioner for the Government of New South WalesThe Minister for Public Works and Health, Department of Public Health, Sydney, Australia (March 31). 